\title{
Effects of Menstrual Cycle Phase on Knee Muscle Activity during One Leg Landing in Non-athletic Females
}

\author{
Ji-Min Lee', Won-Seob Shin ${ }^{2}$ \\ 'Department of Physical Therapy, Graduate School of Health and Medicine, Daejeon University, Daejeon; ${ }^{2}$ Department of Physical Therapy, College \\ of Health and Medical Science, Daejeon University, Daejeon, Korea
}

Purpose: This study investigated the effects of sex hormones across menstrual cycle phases on knee muscle activity during one-leg landing in non-athletic females.

Methods: Twenty-six healthy females who reported normal menstrual cycles for the previous three months were tested when estrogen levels were highest (ovulation) and lowest (menstruation). Knee muscle activity was analyzed based on electromyography (EMG) data recorded during landing on a 30-cm box. Before data collection, each subject was trained in single-leg landing tasks ten times. Landing was analyzed by measuring the average of three landing tasks. EMG data were collected between the moment of ground contact and the point of knee maximum flexion. The maximum voluntary isometric contraction (MVIC) for normalization that was recorded as the EMG root-mean-square (RMS) during landing was tested, with paired t-tests used to assess differences in knee muscle activity according to menstrual cycle phases.

Results: The results showed that the soleus, semitendinosus, and lateral gastrocnemius muscle activity during landing was differed significantly during ovulation compared to that during menstruation $(p<0.05)$. No significant differences in vastus medialis activity were found between menstrual and ovulatory phases during landing $(p>0.05)$.

Conclusion: Changes in the menstrual cycle in response to sex hormones changed the activity of muscles around the knee during landing. Females utilize different muscle activity control strategies during different phases of the menstrual cycle, which may contribute to increased $\mathrm{ACL}$ injury risk.

Keywords: Muscle activity, Estrogen, Landing, Menstrual cycle phase

\section{서 론}

여성은 비슷한 스포츠 활동에서 남자에 비하여 전방십자인대 손 상이 더 많이 일어난다. 전방십자인대 손상 위험과 성별 사이에 차이 는 호르몬의 차이, 해부학적 차이, 생체역학적 차이, 그리고 신경근 특성의 차이를 포함하는 여러 가지 요인에 기인된다. ${ }^{2}$ 여성의 성호르 몬 변화는 선행연구들에서 비접촉성 전방십자인대 손상과 여성 성 호르몬과의 연관성이 확인되었다.,3 여성의 성 호르몬인 에스트로겐 수용기는 골격근과 힘줄에서 확인되고, ${ }^{4}$ 에스트로겐은 근력과 신진 대사 그리고 근경직을 조절한다. ${ }^{5-7}$

성호르몬으로 인해 근육의 특성이 영향을 받는 것은 전방십자인 대 손상에 큰 위험요소로 여겨져 왔다. 이전의 연구에서 근힘줄(musculotendinous)의 경직은 월경주기에 따라 변한다는 것을 발견하였
다. ${ }^{7}$ Lebrun ${ }^{8}$ 은 월경주기의 각 구간에서 등속성 근력, 무산소와 유산 소 능력, 그리고 고강도의 지구력에서 차이가 나타났다고 보고하였 고, 근력도 월경주기의 과정에 따라 차이가 있다고 보고하였다. ${ }^{9}$ 위에 나열된 연구들과 기존의 대다수의 논문들은 정적인 동작에서의 평 가에만 초점을 맞추어 결과를 보고 하였다. 하지만 대부분의 전방십 자인대 손상은 대부분 한발 착지나 사이드 스테핑 등의 스포츠 과제 를 하는 동안에 발생하는 손상이다. ${ }^{10}$ 이러한 동적 과제 동안 스트레 스를 받음으로써 손상은 더욱 자주 발생하게 되며, 매우 적은 연구만 이 월경주기의 변화하는 성호르몬 환경의 양상 하에서 역학과제 동 안 신경근과 생체 역학적 특성, 신경근 조절 패턴의 변화를 평가 하였 다. ${ }^{11,12}$ 그러므로, 월경주기의 뚜렷한 단계 동안에 무릎 관절에 대한 동적인 평가는 전방십자인대 손상 기전의 더 나은 이해를 제공 하며, 동적인 과제에서의 평가에 초점을 맞춘 연구는 매우 드문 실정이다.
Received Sep 19, 2016 Revised Sep 23, 2016

Accepted Oct 12, 2016

Corresponding author Won-Seob Shin

E-mail shinws@dju.kr
Copylight (C)2016 The Korea Society of Physical Therapy

This is an Open Access article distribute under the terms of the Creative Commons Attribution Non-commercial License (Http:// creativecommons.org/license/by-nc/4.o.) which permits unrestricted non-commercial use, distribution, and reproduction in any medium, provided the original work is properly cited. 
착지 시 근육의 활성화는 무릎이나 발목의 손상을 예방하는 주요 요인으로 작용하게 된다. 특히 무릎의 굽힘근과 폄근의 효과적인 동 원은 전방십자인대의 손상을 감소시키고 비대칭적인 근육의 동원은 손상을 일으키게 되며, 남성보다 여성에서 손상의 위험이 높다.13 넙 다리네갈래근, 뒤넙다리근, 장딴지근, 가자미근 힘 생산은 한발 착지 시 관절 운동학을 개선하고 전방십자인대 및 다른 무릎 인대에 가해 지는 부담을 줄이기 위해 활성화될 것이다. ${ }^{14}$ 위의 연구들을 고려했 을 때 한발 착지를 하는 동안 무릎의 안정성을 유지하기 위해서 근육 기능에 의존해야 한다. 그러므로 동적인 과제에서의 평가는 월경주 기의 다른 단계 동안 동적인 안정장치인 근육의 활성 변화를 측정 함 에 있어 매우 중요하다.

본 연구를 통해 착지 시 월경주기에 따라 근육의 활성 변화를 확인 할 수 있는데, 이는 월경주기의 어느 단계에서 손상에 주의해야 하는 지 알 수 있다. 또한 여성의 스포츠 활동 시 무릎의 손상을 예방하기 위해 근육 트레이닝이 필요한데, 본 연구의 결과를 참조하여 월경주 기에 따른 근육의 특성에 맞춰 운동의 강도를 조절할 수 있다. 이러한 이유로 월경주기에 따라서 변하는 근육의 특성은 스포츠 활동을 하 는 여성에게 필요성이 있다. 그러므로 본 연구의 목적은 다른 월경주 기에 따른 성호르몬의 변화가 한발 착지 동안에 무릎주위 근육 활성 에 미치는 영향을 알아보는데 있다.

\section{연구 방법}

\section{1. 연구대상}

본 연구 대상자는 대전광역시에 소재한 $\mathrm{D}$ 대학에 재학 중인 여학 생 26명으로 선정하였고, 어떤 조직화된 운동경기를 참여 하지 않는 비운동선수를 대상으로 하였다. 불규칙적인 월경주기의 가능성을 발생할 수 있는 높은 강도의 훈련에 해당하는 신체활동은 일주일에 7시간 미만으로 제한하였다.15

대상자의 선정 조건은 다음과 같다.

1) 연구하는 동안의 기간을 포함하여 3 개월 동안 안정된 월경주기 를 가진자

2) 초경이 지난 지 1 년 이상이 된 자

3) 임신과 출산을 경험하지 않은 자

4) 연구를 하는 동안과 3 개월 이전에 호르몬 피임제 또는 호르몬 제품을 사용 하지 않은자

5) 하지 관절의 정상 관절 범위가 나오는 자

대상자의 제외 조건은 다음과 같다.

1) 흡연자

2) 결합조직에 영향을 주는 질병을 가진 자

3) 최근 몇 년 동안 하지에 손상이 있는 자
본 연구는 대상자에게 연구의 목적, 진행 과정, 참여의 자발성, 비 밀 보장 등을 충분히 설명하고 협조를 구한 후, 언제든지 연구의 참여 를 포기 할 수 있고, 이로 인한 어떠한 불이익도 받지 않음을 설명하 고 연구의 참여 동의서를 서면으로 작성 받은 후 연구 자료 수집을 시 행하였다.

\section{2. 연구설계 및 절차}

검사자는 측정 시 대상자들의 월경주기를 알지 못하게 하였다. 참 가자들의 우세 다리는 공을 차게 함으로써 우선으로 사용하는 다리 로 정의 하였다. 참가자들은 근전도 부착을 위해 반바지를 입고 측정 을 하는데 각기 다른 신발로 인해 미치는 영향을 피하기 위해 맨발로 하였다. 자연스러운 착지를 위해서 대상자가 10 회 정도 충분한 한발 착지 연습을 시행하도록 하였다. 연습이 끝나고 충분한 휴식을 취한 뒤 높이 $30 \mathrm{~cm}$ 상자에 올라간 후 검사자의 소리에 맞춰 점프를 하였다. 한발착지단계에서 우세다리의 무릎주위의 근육의 활성을 측정하 기 위한 근전도 신호, 각도계 신호, 풋스위치의 신호는 Myosystem (1400A, Noraxon, USA)을 사용하여 기록 되었다. 개폐식 신호(on-off signal)를 제공하는 풋스위치를 사용하여 발이 땅에 닿는 순간을 측 정 했고, 근전도와 함께 기록이 가능한 동적 센서인 각도계를 외측 다리에 부착하여 무릎 각도를 측정하였다. 한발 착지단계는 점프를 한 후 풋스위치가 반응하는 시점부터 무릎 굽힙 각도가 최대가 되는 시점으로 하였다. 착지 후 1-2초 동안 자세를 유지 한다면 성공적인 착 지로 판정하였고, 총 3 회 반복측정하여 평균값을 분석하였다(Figure 1).

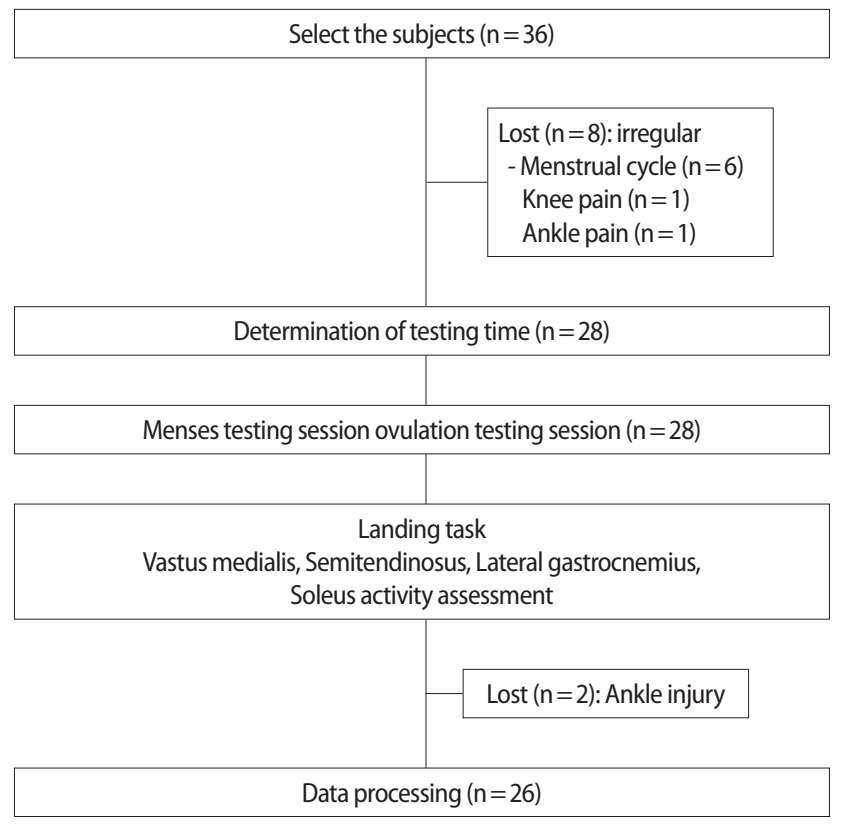

Figure 1. Flow diagram. 


\section{3. 중재방법}

\section{1) 측정 시점의 결정 방법}

모든 대상자의 월경주기는 실험 전에 수집되었고, 대상자는 한달 동안 월경주기의 초기 여포기(월경기)와 배란기에 측정하였다. 참가 자들은 월경주기에서 에스트로겐 레벨이 최저일 때 인 초기 여포기 의 월경기와 에스트로겐이 최고일 때인 배란기로 나누어 실험을 진 행하였다.1516 월경평가 시점은 참가자 스스로 월경의 시작을 알린 후 에 2일 안으로 측정하며, 배란평가 시점은 99\% 정확성을 가진 배란기 테스트기를 사용하여 테스트 용지에 양성이 나타나면, 24-48시간 내 에 측정을 하였다. ${ }^{15}$ 배란일을 추정하기 위해, 각 개인에게 배란기테 스트기(SU-HLHS-01, 수젠텍, 한국)를 제공하여 생리가 끝난 날부터 사용을 시작하도록 하였다. 대상자는 배란기 테스트 용지에 양성이 나타날 때 연구자에게 알리도록 하였다.

\section{2) 한발착지}

한발 착지과제는 높이 $30 \mathrm{~cm}$ 상자에서 수행 하였다. 한발 착지를 위한 준비 자세는 양손은 착지가 끝날 때까지 장골능에 유지시키고, 검사하고자 하는 다리는 무릎을 편 상태로 상자 밖으로 내보내고 지 지하고 있는 반대다리로 점프를 한다. 그리고 착지는 검사하고자 하 는 한쪽다리로만 한다(Figure 2).12

\section{4. 평가 도구 및 방법}

1) 착지 구간 측정

착지 시 발이 땅에 닿는 착지시작 시점을 알기 위해 풋스위치(Model 500 DTS FootSwitch; Noraxon Inc., USA)를 사용하였다. 풋 스위치의 센서는 발바닥에 테이프로 부착된다. 부착되는 부위는 발 앞꿈치와 뒤꿈치에 부착하였다.

착지 종료 지점은 한발 한발 착지에서 무릎이 최대로 굽힘되는 시 점으로 하고, 전자 각도 계(Model 508 2D Electrical Goniometer; Noraxon Inc., Scottsdale, AZ, USA)을 사용하여 측정하였다. 전자각도계는 양쪽에 엔드블록(endblock)이 있고 가운데 스프링으로 연결되어 있 다. 대상자는 평평한 표면에서 자연스러운 자세로 선다. 시상면에서, 먼쪽 엔드블록은 다리의 축을 따라 가쪽으로 붙인다. 앞에서 언급한 자세에서 각도계가 길어지게 끔 다리를 완전히 편다. 그 후 몸쪽 엔드 블록은 허벅지의 축을 따라 붙였다.

\section{2) 근전도}

표면 근전도(Myosystem 1400A, Noraxon Inc., USA)를 사용하였고, 근전도 신호는 MyoResearch XP Master edition 1.06 program (Noraxon Inc.)을 사용하여 저장하고 처리하였다. 근전도의 자료수집은 점프 후 발이 땅에 닿아 풋 스위치가 반응하는 시점에서부터 무릎 굽힘각

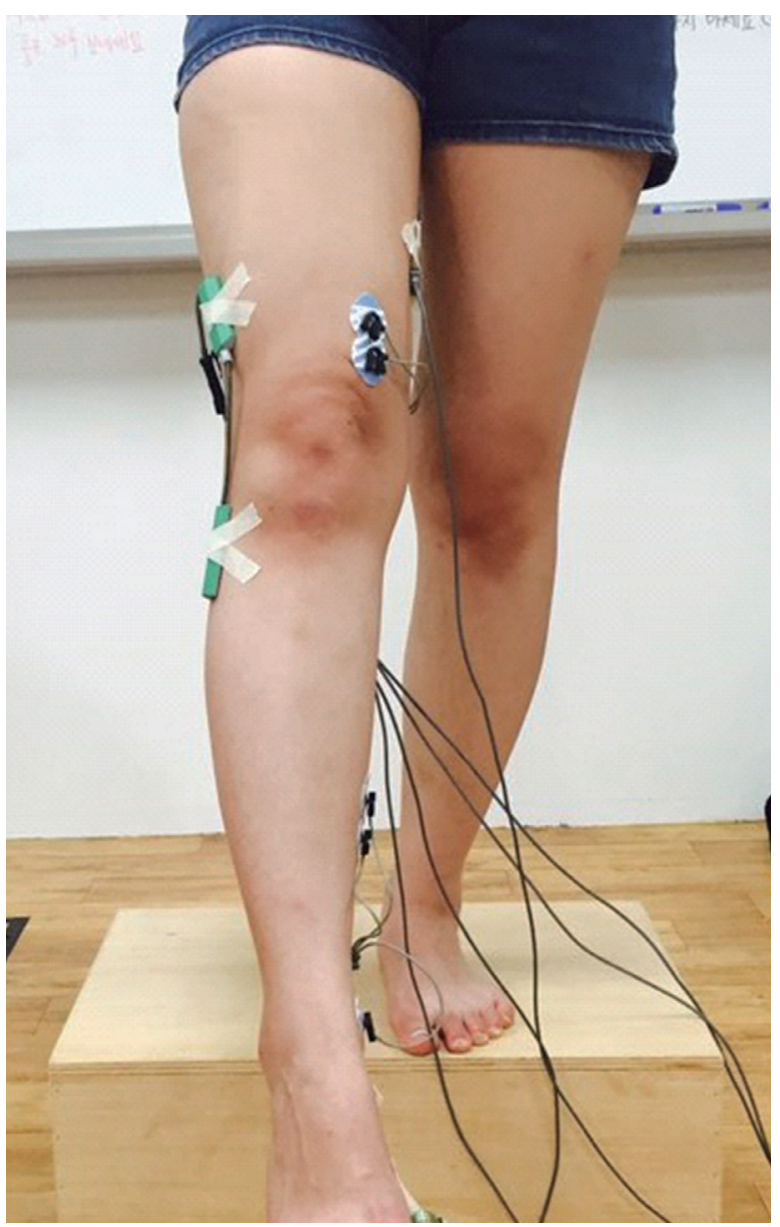

Figure 2. The starting position of one leg landing.

이 최대(knee maximum flexion)되는 시점까지의 구간을 착지로 보았 고, 이 시점에서 발생하는 신호를 측정 하여 사용 하였다.

측정 전 표면 전극(T246H, G\&S international, 한국)은 전극 부착 부 위를 면도 한 뒤 부착하는데, 이는 피부 저항을 최소화하기 위함이 다. 안쪽 넓은근, 반힘줄근, 가쪽 장딴지근, 가자미근에 각각 $20 \mathrm{~mm}$ 의 전극 간 거리를 가진 두 개의 활성 전극을 근육의 근복에 부착하였 고, 접지 전극은 발목의 복사뼈에 부착하였다. 착지 시 발생 할 수 있 는 인공 잡음을 해결하기 위해 근전도 전기선은 접착 테이프를 이용 하여 착지하는 다리에 꼬이지 않게 부착 하였다.

근전도 신호는 생체 신호에 대한 아날로그 신호를 디지털화 하여 신호 획득률(sampling rate)은 $1,000 \mathrm{~Hz}$ 로 수집한 후, 수집된 데이터는 $20-500 \mathrm{~Hz}$ 대역필터(band-pass filter)와 완파정류(full-wave rectification) 한 후에 $50 \mathrm{~Hz}$ 저역필터(low-pass filter)를 사용하여 처리를 하고, 실효 치값(root mean square, RMS)을 컴퓨터 파일로 저장하여 자료 처리에 이용하였다.

안쪽 넓은근, 반힘줄근, 가쪽 장딴지근, 가자미근의 근활성도는 각 각 수의적 최대 등척성근수축(MVIC) 동안에 수집되었고, 위에서 언 
Table 1. General characteristic of subjects $(n=26)$

\begin{tabular}{lrl}
\hline & Mean & SD $^{*}$ \\
\hline Age (year) & 22.62 & 2.32 \\
Height $(\mathrm{cm})$ & 162.31 & 4.09 \\
Weight $(\mathrm{kg})$ & 56.87 & 7.60 \\
Menstrual Cycle (day) & 29.81 & 4.49
\end{tabular}

*SD, standard deviation.

급한 한발 착지 동안에도 수집되었다. 본 연구는 한발 착지 동안에 수 집되는 EMG RMS를 표준화 하기 위해 $150 \mathrm{~ms}$ 넘어 기록되는 MVIC RMS 값을 사용 하였다. ${ }^{7}$ 안쪽 넓은근의 측정은 앉은 상태에서 무릎 을 70 도와 90 도 사이로 굽힌 자세에서 의자 다리에 한쪽 발목을 고정 하고 무릎 신전을 수행하였다. 반힘줄근의 MVIC 측정은 엎드린 상 태에서 고관절은 고정하고 수행하는 한쪽 다리는 무릎을 20-30도 구 부린 자세에서 수행하였다. 장딴지근의 측정은 앉은 상태에서 무릎 을 신전해 벽에 발바닥 전체가 닿게 하며, 이때 고관절은 고정되어 있 는 상태이고, 족저가 90 도 굽힘된 발목자세에서 발바닥 굽힘을 수행 하였다. 가자미근의 측정 자세는 바르게 앉은 자세에서, 한쪽을 발바 닥 굴곡 수행하고, 수행 시 무릎을 단단히 고정하는 것은 강한 힘 때 문에 필요하다.18

\section{5. 분석 방법}

실험 결과 자료의 통계 처리는 SPSS version 22.0을 사용할 것이고, 연구 대상자의 일반적인 특성은 기술통계를 사용하여 분석하였다. 한발착지 시 그룹 내 월경주기의 두 시점에서 각 근육 활성에 변화를 비교하기 위해 대응 표본-t검정(paired-t test)을 실시 하였고, 통계적 유 의성을 검정하기 위한 유의수준은 $\alpha$ 는 0.05 로 하였다.

\section{결 과}

\section{1. 대상자의 일반적인 특성}

본 연구에 참가한 대상자는 총 26명으로 나이, 신장, 체중, 월경주 기의 평균과 표준편차는 다음과 같다(Table 1).

\section{2. 착지 시 무릎주위 근육에 활성 비교}

착지 시 각 근육의 활성은 초기 여포기와 배란기 모두에서 안쪽 넓 은근이 가장 높았고, 가자미근, 반힘줄근, 가쪽 장딴지근의 순서로 나 왔다. 착지 시 월경주기에 따른 각 근육의 근활성도 차이 비교에 대한 결과는 초기 여포기에 비해 배란기때 가자미근, 반힘줄근, 가쪽 장딴 지근 순서로 유의 하게 증가였고 $(\mathrm{p}<0.05)$, 안쪽 넓은근은 통계학적으 로 유의하지 않았다( $\mathrm{p}>0.05)$ (Table 2).
Table 2. Comparison of muscles activity (\%MVIC) between the phases $(n=26)$

\begin{tabular}{lccc}
\hline & $\begin{array}{c}\text { Early follicular } \\
\text { phase }\end{array}$ & $\begin{array}{c}\text { Ovulatory } \\
\text { phase }\end{array}$ & p-value \\
\hline Vastus medialis & $189.35 \pm 82.02$ & $191.95 \pm 93.36$ & 0.774 \\
Semitendinosus & $86.89 \pm 40.49$ & $110.70 \pm 37.25$ & $0.001^{*}$ \\
Lateral gastrocnemius & $43.39 \pm 15.35$ & $55.40 \pm 24.11$ & $0.019^{*}$ \\
Soleus & $94.01 \pm 62.49$ & $127.87 \pm 66.97$ & $0.000^{*}$ \\
\hline
\end{tabular}

Values are mean $\pm S D,{ }^{*} p<0.05$

MVIC: maximum voluntary isometric contraction.

\section{고 찰}

본 연구는 여성의 월경주기에 따른 성호르몬 변화가 한발 착지 동 안에 무릎주위 근육의 활성에 미치는 영향을 알아내는 것을 목적으 로 한발 착지 시 근전도를 이용하여 무릎주위 근육의 활성를 분석하 는 방법으로 시행하여 다음과 같은 결과를 보였다.

이전 선행연구에서 착지동안에 무릎 주위 근육에 대한 근전도 분 석은 여성의 넙다리 네갈레근의 활성이 뒤넙다리근에 비해 약 2 배정 도 높다고 하였다. ${ }^{1920}$ Shultz와 Schmitz'는 착지 시 초기 지면 접촉 후 단계 동안에 여성의 근육활성은 넙다리 네갈래근의 내측 활성이 뒤 넙다리근의 내측 활성보다 더 높다고 하였고, 본 연구 결과에서도 월 경 시점과 배란 시점에서 모두 반힘줄근에 비해 안쪽넓은근의 활성 이 높게 나타났다. 또한 선행연구에서 착지시 평균 근전도 값과 근활 성도를 본 선행연구에서는 넙다리 네갈래근에서 가장 높게 나타났 고, 그 다음은 뒤넙다리근, 장딴지근 순으로 나타났으며, ${ }^{22}$ 본 연구에 서도 착지 시 두 시점 모두에서 근활성이 위의 선행연구와 유사한 결 과가 나왔다. 본 연구에서 발목관절의 안정성 근육인 가자미근의 착 지시 활성은 두 시점 모두에서 뒤넙다리근과 장딴지근보다 더 높게 나왔으며, 앞서 말한 결과는 Mokhtarzadeh 등 23 과 Iida 등 ${ }^{24}$ 의 연구가 뒷받침한다. 선행연구와 마찬가지로 본연구에서의 착지 시 근육의 활 성도 크기는 넙다리 네갈래근, 가자미근, 뒤넙다리근, 장딴지근의 순 서로 나타났다.

본 연구에서 착지 시 초기 여포기에 비해 배란기에서 근활성도가 증가하는 변화를 확인할 수 있는데, 이는 월경주기에서 에스트로겐 이 가장 높은 시기인 배란기에 전방십자 인대가 가장 이완되는 결과 와 관련이 있다. ${ }^{5}$ 한발 착지는 전방십자인대에 손상 위험을 증가 시키 며, ${ }^{10}$ 착지 시 신체의 충격을 흡수하기 위해 하지의 골격과 근육에서 적절한 조절을 필요로 하고, ${ }^{25}$ 이때 충격이 신체 능력 이상일 경우에 부상이 발생할 수 있다. ${ }^{26}$ 이는 한발 착지 시 근육의 적절한 조절이 전 방십자인대 손상을 줄인다고 하고 있으며, 전방십자인대가 이완된 경우에는 무릎의 안정성을 위해 더 큰 근육의 활성이 필요하다는 것 을 추정 할 수 있다. 본 연구에서 초기 여포기에 비해 배란기에 측정 
한 근육 모두에서 증가하였고, 그 중 가자미근, 반힘줄근, 외측 장딴 지근이 유의하게 증가하였는데, 이러한 결과는 아래에 선행연구들 에 의해 증명된다. 한발 착지 시, 시상면에서 경골 전방 이동(anterior tibial translation)은 전방십자인대에 의해 제한되며, 전방 무릎 안정성 을 제공하는 데 있어 뒤넙다리근은 전방십자인대에 부과되는 무게 를 줄이는 무릎의 주요한 동적인 안정장치이며, 주동근이라고 하였 다. ${ }^{27}$ 뒤넙다리근과 마찬가지로 장딴지근과 가자미근이 잠재적으로 전방십대인자손상 위험을 감소시킬 수 있기 때문에 착륙하는 동안 무릎을 지지하는 데 발목관절의 안정성 근육들의 역할이 중요하다.14 한발 착지 동안 발목관절의 안정성 근육 중 특히 가자미근은 뒤넙다 리근과 비슷하게 경골의 후방이동을 만드는 중요한 역할을 하고, 이 는 무릎의 안정성에 기여하는 기여한다. ${ }^{23}$

선행 연구자들은 비접촉성 전방십자인대 부상의 잠재적인 위험 요 소로서 월경주기의 호르몬 변화를 요인으로 포함하였다. ${ }^{28}$ 여성 월경 주기 동안에 전방십자인대 손상과 성 호르몬의 변화 사이의 관계는 논 란이 많다. 몇몇 연구들은 전방십자인대 손상의 발생 정도가 후기 여 포기와 황체기 동안에 높다고 하였다. ${ }^{29}$ 하지만 많은 연구들은 에스트 로겐 레벨이 최저가 되는 초기 여포기 때 전방십자인대 손상이 많았 다.15,16,30 Shultz 등그는 배란 전의 단계(월경에서 배란까지의 단계)에서 가장 큰 위험을 보인다고 하였다. 또한 James 등른 전방십자인대 손상 이 월경시작 후 1-2일에 가장 빈번하고, 전방십자인대 손상은 불규칙하 게 나타나는 것이 아니고 초기 여포기에 더 발생한다고 제안하였다. 근육의 특성이 전방십자인대 손상에 큰 위험 요소로 여겨져 왔으며, 이러한 근육의 특성은 성호르몬에 의해 영향 받는다는 것이 발견되어 왔다. 근육의 수축에 의한 관절 압박은 무릎 인대들을 보호하기 위해 서 경골 전방 이동과 외반력을 제한할 수 있다고 하였다. ${ }^{28} \mathrm{Markolf}$ 등 33 은 무릎에 대한 근육 활성은 무릎 안정성에 대해서 근육 시스템의 영 향을 강조하는 외반 안정성이 3 배 증가된다고 발견하였고, Eiling 등 34 과 Dedrick 등'2은 손상의 위험을 증가시킬 수 있는 방법들인 근경직과 신경근 활성 패턴이 월경주기에 따라 변한다는 것을 발견하였다. 그러 므로 무릎에 손상과 관련하여 여성의 월경 주기는 무릎 안정성의 능 동적 안전 장치인 근육에 큰 영향을 미칠 것으로 생각한다.

Shultz 등 35과 Khowailed 등15은 에스트로겐이 최고 일 때(배란기)와 에스트로겐이 최저(초기 여포기)일 때 측정하였다. 이에 따라 본 연구 도 각각 개인의 월경주기에서 에스트로겐이 최저일 때인 초기 여포기 와 최고인 배란기 두 가지 시점으로 나눠서 실험을 진행하였다. 전방 십자인대 손상 발생 정도는 초기 여포기 동안에 높은 것으로 보고 되 어 왔다. 하지만 무릎 이완에 대한 정적 평가는 후기 여포기와황체기 동안 증가 한다고 보고 하였고, ${ }^{29}$ 이는 전방십자인대의 높은 손상 발 생 정도에 특정한 월경주기 단계와 증가된 조직이완에 특정한 월경주 기는 서로 모순된다. 그러므로 월경주기의 뚜렷한 단계 동안에 무릎
관절에 대한 동적 평가는 전방십자인대 손상 기전의 더 나은 이해를 제공하며, 동적 평가는 하중 작업을 하는 동안에 발생하는 손상 시나 리오를 모방한다. 동적 평가 동안에 수동적 그리고 동적 안전장치 둘 다 무릎 안정성을 증진시키는데 기여하는 반면에, 정적 평가는 오직 무릎의 수동적 안전장치의 활동만 강조한다. Arampatzis 등 25 은 착지 를 할 때 하지의 근육의 적절한 조절을 통하여 신체의 충격 흡수를 하 게 된다고 하였다. 그러므로 본 연구에서는 동적 연구를 시행하여 착 지 시 하중을 받는 동안에 발생하는 근육의 활성도를 알아 보았다.

본 연구의 결과는 호르몬의 변화가 근육에 영향을 줄 수 있다는 것을 객관적으로 도출해 낼 수 있으며, 이것은 운동을 하는 일반적인 여성에게 월경주기에 어느 단계에서 주의해야 하는지를 알려주는 평 가로서 임상에서 유용하게 사용될 것으로 예상된다. 또한 일반적으 로 전방십자 인대 손상에 영향을 미치는 넙다리 네갈래근의 특성으 로 위축(atrophy)와 약화(weakness)을 들수있는데, ${ }^{36}$ 본 연구를 통해 여자 선수들에게는 스포츠 활동 시 부상예방을 위해서는 안쪽 넓은 근보다는 뒤넙다리근과 가자미근에 중점적인 근력강화가 필요함을 알 수 있다. 뒤넙다리근 근력을 증가시키는 것은 전방십자인대 손상 재활과 예방에서 중요한 요소로 고려 될 수 있고, 근력 트레이닝을 포 함하는 손상 방지 프로그램은 손상 위험을 감소시킨다. ${ }^{37}$ 본 연구의 결과는 스포츠 활동 시 여성의 월경주기에 변화에 따라서 전방십자 인대 손상 예방을 할 수 있기 때문에 임상적 의의가 있다고 생각한다.

본 연구의 제한점으로 첫째는 대상자의 연령이 20대의 여학생으로 만 모집이 되었으므로, 월경을 하는 전체 연령의 여성을 일반화하기 에는 어려움이 있을 것이다. 향후 더 다양한 연령을 여성을 대상으로 한 많은 연구가 필요 할 것으로 생각한다. 두 번째는 특정한 운동을 하지 않는 비운동선수 여성을 대상자로 선정 하였기 때문에, 여성 스 포츠 선수들로 결과를 일반화 하기는 어렵다. 그렇기 때문에 운동선 수여성을 추가로 한 연구가 필요할 것으로 생각한다.

본 연구의 결과는 착지 시 월경 주기에 변화가 근육 활성에 영향을 미치는 것을 알 수 있었다. 또한 Dedrick 등르는 착지 시 손상의 위험을 증가시킬 수 있는 신경근 활성 패턴(neuromuscular activation patterns) 이 월경주기에 따라 변한다는 것을 발견하였고, 뒤넙다리근의 개시 시간에 변화는 전방십자 인대 손상에 영향을 미친다고 하였다.38 위 의 선행연구와 같이 많은 연구들은 착지 시 근수축 개시시간에 초점 을 맞추고 있다. 그러므로 향후 연구에서도 착지 수행 시 신경근 활성 패턴의 변화가 월경주기에 따라서 변화하는지에 대해서 알아볼 필 요가 있다.

\section{참고문헌}

1. Arendt EA, Agel J, Dick R. Anterior cruciate ligament injury patterns among collegiate men and women. J Athl Train. 1999;34(2):86-2. 
2. Ireland ML, Ott SM. Special concerns of the female athlete. Clin Sports Med. 2004;23(2):526-36.

3. Slauterbeck JR, Fuzie SF, Smith MP et al. The menstrual cycle, sex hormones, and anterior cruciate ligament injury. J Athl Train. 2002;37(3): 275-8.

4. Wiik A, Elkman M, Johansson O et al. Expression of both oestrogen receptor alpha and beta in human skeletal muscle tissue. Histochemistry and Cell Biology. 2009;131(2):181-9.

5. Sarwar R, Niclos BB, Rutherford OM. Changes in muscle strength, relaxation rate and fatiguability during the human menstrual cycle. Journal of Physiology, London. 1996;493:267-72.

6. Hackney AC. Influence of oestrogen on muscle glycogen utilization during exercise. Acta Physiol Scand. 1999;167(3):273-4.

7. Eiling E, Bryant AL, Petersen A et al. Effects of menstrual-cycle hormone fluctuations on musculotendinous stiffness and knee joint laxity. Knee Surg Sports Traumatol Arthrosc. 2007;15(2):126-32.

8. Lebrun CM. The effect of the phase of the menstrual cycle and the birth control pill in athletic performance. Clin Sports Med. 1994;13(2):419-41.

9. Sarwar R, Niclos BB, Rutherford OM. Changes in muscle strength, relaxation rate and fatiguability during the human menstrual cycle. Journal of Physiology, London. 1996;493:267-72.

10. Koga H, Nakamae A, Shima Y et al. Mechanisms for noncontact anterior cruciate ligament injuries: knee joint kinematics in 10 injury situations from female team handball and basketball. Am J Sports Med. 2010;38(11): 2218-25.

11. Abt JP, Sell TC, Laudner KG et al. Neuromuscular and biomechanical characteristics do not vary across the menstrual cycle. Knee Surg Sports Traumatol Arthrosc. 2007;15:901-7.

12. Dedrick GS, Sizer PS, Merkle JN et al. Effect of sex hormones on neuromuscular control patterns during landing. J Electromyogr Kinesiol. 2008; 18(1):68-78.

13. Yukio U, Risa K, Sachiko S et al. Electromyo-graphic analysis of the knee during jump landing in male and female atheletes. The Knee. 2005;12(2): 129-34.

14. Podraza JT, White SC. Effect of knee flexion angle on ground reaction forces, knee moments and muscle co-contraction during an impact-like deceleration landing: implications for the non-contact mechanism of ACL injury. The Knee. 2010;17(4):291-5.

15. Khowailed I A, Petrofsky J, Lohman E et al. 17 $\beta$-estradiol induced effects on anterior cruciate ligament laxness and neuromuscular activation patterns in female runners. Journal of Women's Health. 2015;24(8);670-80.

16. Shultz SJ, Sander TC, Kirk SE et al. Sex differences in knee joint laxity change across the female menstrual cycle. J Sports Med Phys Fitness. 2005; 45(4):594-603.

17. Klyne DM, Keays SL, Bullock-Saxton JE et al. The effect of anterior cruciate ligament rupture on the timing and amplitude of gastrocnemius muscle activation: a study of alterations in EMG measures and their relationship to knee joint stability. J Electromyogr Kinesiol. 2012;22(3):44655.

18. Konrad P. The abc of emg. j jacc. 2005;1016(10):1-60.

19. Jung KK, Sang JC. The effects of maximal muscle contraction exercise induced muscle soreness on lower extremities muscle activities, angles of knee and ankle in drop landing. Journal of Sport and Leisure Studies. 2015;59(2):195-805

20. Hughes G, Dally N. Gender difference in lower limb muscle activity dur- ing landing and rapid change of direction. Science \& Sports. 2015;30(3): 163-8.

21. Shultz SJ, Schmitz RJ. Effects of transverse and frontal plane knee laxity on hip and knee neuromechanics during drop landings. Am J Sports Med. 2009;37(9):1821-30.

22. Chul SH. Biomechanical analysis on drop landing type. The Korea Journal of Sports Science. 2013;22(2):1287-96

23. Mokhtarzadeh $\mathrm{H}$, Yeow CH, Hong Goh JC et al. contributions of the soleus and gastrocnemius muscles to the anterior cruciate ligament loading during single-leg landing. Journal of Biomechanics. 2013;46(11):1913-20.

24. Iida Y, Kanehisa H, Inaba Y et al. Activity modulations of trunk and lower limb muscles during impact-absorbing landing. J Electromyogr Kinesiol. 2011;21(4):602-9.

25. Arampatzis A, Morey-Klapsing G, Bruggemann GP. The effect of falling height on muscle activity and foot motion during landings. J Electromyogr Kinesiol. 2003;13(6):533-44.

26. Duffk JS, Bates BT. The evaluation and prediction of impact forces during landing. Medicine and Science in Sports and Exercise. 1990;22(3): 370-7.

27. Tsepis E, Vagenas G, Giakas G et al. Hamstring weakness as an indicator of poor knee function in ACL-deficient patients. Knee Surg Sports Traumatol Arthrosc. 2004;12(1):22-9.

28. Hewett TE, Myer GD, Ford KR. Anterior cruciate ligament injuries in female athletes: part 1, mechanisms and risk factors. Am J Sports Med. 2006;34(2):299-311.

29. Deie M, Sakamaki Y, Sumen Y et al. Anterior knee laxity in young women varies with their menstrual cycle. Int Orthop. 2002;26(3):154-6.

30. Arendt EA, Bershadsky B, Agel J. Periodicity of noncontact anterior cruciate ligament injuries during the menstrual cycle. J Gend Specif Med. 2002;5(2):19-26.

31. Shultz SJ, Schmitz RJ, Nguyen AD et al. ACL Research Retreat V: an update on ACL injury risk and prevention. J Athl Train. 2010;45(5):499508.

32.James R, Stephen F, Michael P et al . The menstrual cycle, sex hormones, and anterior cruciate ligament injury. J Athl Train. 2002;37(3):275-80.

33.Markolf KL, Graff-Radford A, Amstutz HC. In vivo knee stability: a quantitative assessment using an instrumented clinical testing apparatus. J Bone Joint Surg [Am]. 1978;60(5):664-74.

34. Eiling E, Bryant AL, Petersen W et al. Effects of menstrual-cycle hormone fluctuations on musculotendinous stiffness and knee joint laxity. Knee Surg Sports Traumatol Arthrosc. 2007;15(2):126-32.

35. Shultz SJ, Gansneder BM, Sander TC et al. Absolute serum hormone levels predict the magnitude of change in anterior knee laxity across the menstrual cycle. Journal of Orthopaedic. 2006;24(2):124-31.

36. Tsepis E, Vagenas G, Ristanis S et al. Thigh muscle weakness in ACL-deficient knees persists without structured rehabilitation. Clin Orthop Relat Res. 2006;450:211-8.

37. Yoo JH, Lim BO, Ha M, et al. A meta-analysis of the effect of neuromuscular training on the prevention of the anterior cruciate ligament injury in female athletes. Knee Surg Sports Traumatol Arthrosc. 2009;18(6): 824-30.

38. Swanik CB, Lephart SM, Swanik KA et al. Neuromuscular dynamic restraint in women with anterior cruciate ligament injuries. Clin Orthop Relat Res. 2004;425:189-99. 